Okay Demir ${ }^{1} \mathrm{PhD}$

Original scientific paper

Ministry of Education, Science and Art Center in Malatya

UDC: 37.022

Malatya, Turkey

Prof Dr Suleyman Nihat Sad ${ }^{2}$

Inonu University, Faculty of Education Department of

Curriculum and Instruction, Malatya, Turkey

\title{
INVESTIGATION OF THE COMMUNICATION SKILLS, PROFESSIONAL SENIORITY, SCHOOL STAGE AND GENDER AS PREDICTORS OF TEACHERS' CLASSROOM MANAGEMENT STYLES
}

\begin{abstract}
This study aimed to test the impacts of communication skills, professional seniority, school stages and gender as predictors of teachers' classroom management styles. Survey and correlation research designs were used in the research. The study group of the research consists of 209 teachers from different subject fields. Classroom Management Styles Scale and Communication Skills Scale-Adult Form were used to collect data in the study. The data obtained were mainly analyzed by multiple regression analysis. Regarding the results of the study, when the teachers' levels of classroom management style scores were examined, it was determined that the most preferred classroom management style was Authoritative style, followed by Authoritarian and Laissez-faire styles, respectively, and the least used classroom management style were Indifferent. Also, it was found that teachers' general communication skills are high. The regression analyses revealed that while Basic Skills and Self-Expression and Active Listening and Non-verbal Communication variables were significant predictors of authoritative classroom management, professional seniority was the only significant predictor of authoritatian classroom management, and Basic Skills and Self-Expression and Willingness to Communicate variables were significant predictors of Indifferent classroom management. However, none of the variables were significant predictors of Laissez-faire classroom management style.
\end{abstract}

Keywords: Classroom management styles, communication skills, teachers.

\section{Introduction}

If education management refers to the application of the management to education and the school management refers to the application of management to the schools, classroom management refers to the application of the management to the classroom (Toprakci, 2004). Classroom management is the implementation of school and education management in the limited context of classroom (Basar, 2004). From the management perspective, the classroom is not a physical room which consists of some equipment and materials including computers, desks, tables, chairs, books, and a blackboard or a smartboard. It is an environment where intense and continuous communication between teacher and students and among students

\footnotetext{
1 okay4425@gmail.com.

2 nihat.sad@inonu.edu.tr.
} 
takes place in line with some educational goals. In this complex, managing such an environment requires extensive knowledge of what may happen in the classroom, the ability to process a good amount of information rapidly, and the ability to perform effective actions and reactions sustainably (Djigic \& Stojiljkovic, 2011).

In the classroom environment, especially in group-based education systems, classroom management is very important in establishing and maintaining order, in addition to the social and emotional development of students. The main purpose of classroom management strategies is to support behaviors that are appropriate especially in the classroom environment by improving students' behaviors that do not conflict with social realities, as well as ensuring their academic participation (Emmer \& Sabornie, 2015; Evertson \& Weinstein, 2006). At this point, teachers' classroom management styles become important as one of the critical concepts in the effective and productive execution of the learning-teaching process (Aktan \& Sezer, 2018). When the literature is reviewed, we can find some approaches that identify teachers' classroom management styles from different perspectives. According to Martin and Baldwin (1993), what a teacher does for her students to learn, her perspective on discipline, and her belief towards the student as an individual should be taken into account in determining the classroom management style of a teacher. According to Wolfgang and Glickman (1980), there are three types of class management styles: Interventionist, NonInterventionist and Interactionalist. Non-Interventionist classroom management style is the least directional and controlling, and in this style, the teacher believes that the children have an intrinsic drive which needs to be expressed naturally. On the other hand, the Interventionist approach is more controlling and emphasizes the use of excessive control over the classroom activities. In the middle of these two extremes is the Interactionalist management style that tries to solve problems in a way that satisfies both the teachers and students (Chambers \& Hardy, 2005; Ritter \& Hencock, 2007). Bosworth (1997) suggests that teachers basically have four classroom management styles: Authoritarian, Authoritative, Laissez-faire and Indifferent. In this study, Bosworth's (1997) classification of class management styles, which is generally used in the literature, was used. The characteristics of these classroom management styles are summarized below (Aktan \& Sezer, 2018; Bosworth, 1997; Crosbie-Burnett \& Giles-Sims, 1994; Ekici, 2004; Talsik, 2015):

a) In the authoritarian style, the teacher is control-oriented and sets strict rules on the students. There is always a traditional sitting order in the classroom. Students should be sitting on their desks at the beginning of the lesson and it is not welcome to move from their desks. Students are rarely allowed do activities and they know that they should not disturb the teacher. There is no opportunity for students to gain or apply communication skills as there is no room for discussion activities in the classroom. Teachers who use the Authoritarian classroom management style prefer excessive discipline and expect obedience from students. Failure to obey a teacher often leads to staring eyes of the teacher or some disciplinary action. In such classes, students are expected to follow instructions without questioning the reasons.

b) In the authoritative style in classroom management, the teacher sets limits and controls the students, but also encourages them to act independently. In this style, the teacher often explains the reasons behind the rules and her decisions. Teacher may apply sanctions only after carefully considering of the circumstances.

c) In the Laissez-faire style, the teacher exerts little control over the students and prefers to minimally monitor the student's behavior by accepting their impulses and actions. The teacher tries not to hurt the student's feelings and has difficulty saying no to a student or enforcing the rules. In this style, the teacher is concerned with the emotional well-being of their students 
rather than classroom control, and sometimes bases her classroom decisions on students' emotions rather than academic concerns.

d) In the indifferent style, the teacher is not very much interested in the classroom. This teacher makes little demands on students and often appears indifferent. Indifferent teacher does not put pressure on students on any academic matters and therefore believes class preparation is not worth any effort. In this teacher's lessons, there is no room for academic tasks such as field trips or projects. The teacher using this style lacks the ability, self-confidence or courage to discipline students. In such classes, learning takes place at a very low level, because students also feel this indifferent attitude of the teacher and reflect it to their performance. The teacher tries to kill the lesson time.

Teachers' attitudes and ways of communication with students play an important role in teachers' display of classroom management styles (Ekici, 2004). Since teachers' attitudes and behaviours towards their students also affect students' attitudes, behaviours and interests towards their teachers and the lesson, teachers' communication skills are considered very important (Ugurlu, 2013). As the nature of communication requires, teachers convey messages to their students during educational processes. This communication between teachers and students is a very complex process in which more than one recipient is involved, and therefore teachers should be effective communicators while interacting with the students (Halimah \& Sukmayadi, 2019). Teachers need to have highly developed communication skills to be successful professionals. Teachers must have highly developed oral and written communication skills to communicate effectively with management, students and colleagues (Ihmeideh, AlOmari, \& Al-Dababneh, 2010). Effective communication skills are inevitably important for a teacher to ensure that she performs teaching, classroom management and interaction with students efficiently (Khan, Khan, Zia-Ul-Islam, \& Khan, 2017). In this respect, a teacher's ability to communicate effectively is directly related to the excellence instruction.

The literature is well-documented with studies examining teachers' classroom management styles and communication skills in terms of various variables. For example, Yilmaz (2011) examined the relationship between primary school teachers' classroom management styles and their views on democratic values, and found that there are low-level significant relationships between these variables. In the same study, it was found that there was no significant difference in teachers' classroom management styles according to gender variable, but there was a significant difference in authoritarian classroom management style in terms of branch variable, in protective classroom management style in terms of education level and age, and in indifferent classroom management style according to branch, education level and seniority variables. In their study examining the classroom management skills of preschool teachers, Guven and Cevher (2005) did not find a significant difference in classroom management skills of teachers in terms of professional seniority, class size, socio-economic level of the milieu of the school and state of having any in-service training on classroom management, but they found significant differences in terms of status and type of school worked. Unlu (2020) examined classroom management styles of classroom teachers, and determined that classroom management styles did not differ according to gender, but differed according to professional seniority.

There are studies that examine teachers' communication skills in terms of similar variables. For example, Ozgok and Ciftci (2020) examined the communication skills of classroom teachers and stated that there are generally significant differences according to gender and professional seniority; however, there were no significant differences according to the place of work. Durukan and Maden (2010) examined the communication skills of Turkish teachers and revealed 
that there are significant differences in terms of gender, professional seniority, and graduation variables. Akuzum and Ozdemir Gultekin (2017) stated that the communication skills of classroom teachers differ significantly according to the gender variable, and accordingly, female teachers feel themselves more competent than male teachers in terms of communication skills; and there were significant differences in terms of professional seniority, age, class size variables.

When the literature is examined, it is seen that there are studies investigating the teachers' classroom management styles (Adedigba \& Sulaiman, 2020; Barrosa \& Dias, 2020; Berger \& Girardet, 2020; Debbag \& Fidan, 2020; Guzeldere Aydin \& Ocak Karabay, 2020; Juta \& Wyk, 2020; Obiekwe \& Ogbo, 2020) and communication skills (Claro, et al., 2018; Ihmeideh, Al-Omari \& AlDababneh, 2010; Siddiq, Scherer \& Tondeur, 2016; Yesil, 2010; Yusof \& Halim, 2014), however we have not found any study which investigate the impact of teachers communication skills, together with gender, professional seniority and school stage, on their classroom management styles. In this context, this study aimed to fill this gap and to test the impacts of communication skills, professional seniority, school stages and gender as predictors of teachers' classroom management styles. In line with this purpose, answers were sought to the following research questions:

1. Are teachers' communication skills, professional seniority, gender, and school stage significant predictors of their Authoritative classroom management style?

2. Are teachers' communication skills, professional seniority, gender, and school stage significant predictors of their Authoritarian classroom management style?

3. Are teachers' communication skills, professional seniority, gender, and school stage significant predictors of their Laissez-faire classroom management style?

4. Are teachers' communication skills, professional seniority, gender, and school stage significant predictors of their Indifferent classroom management style?

\section{METHOD}

\section{Design}

The present study, which aims to test the impacts of teachers' communication skills, professional seniority, school stages and gender as predictors of their classroom management styles, was designed as a correlational research, following a baseline survey design. The survey was used as a baseline model to reveal teachers' classroom management styles and communication skills, since it aims to collect data to determine certain characteristics of a group (Buyukozturk, Cakmak, Akgun, Karadeniz, \& Demirel, 2014; Neuman, 2013). Also, as its main purpose is to determine the direction and strength of the relationships between variables (Punch, 2011), the correlational design was used to determine the relationship between teachers' communication skills, gender, professional seniority, and school stages and the classroom management styles of the teachers.

\section{Study group}

The participants of the study consisted of 209 teachers who volunteered to participate. The schools were closed due to the global epidemic of Covid-19 in the 2020-2021 academic year and large-scale measures were taken to prevent the spread of the epidemic. Thus face-to-face interaction with teachers could not be established, so the research data were collected online. Accordingly, teachers were reached through closed social media groups where teachers share their academic experiences and materials. Instruments were sent to and collected from the 
teachers via Google forms application. Information about the teachers who participated into the study are given in Table 1 .

Table 1. Information about participating teachers $(\mathrm{N}=209)$

\begin{tabular}{|c|c|c|c|}
\hline Variable & Group & $f$ & $\%$ \\
\hline \multirow{3}{*}{ Gender } & Women & 113 & 54 \\
\hline & Men & 96 & 46 \\
\hline & Total & 209 & 100 \\
\hline \multirow{4}{*}{ School stage } & Primary & 76 & 36 \\
\hline & Middle & 101 & 48 \\
\hline & High & 32 & 15 \\
\hline & Total & 209 & 100 \\
\hline \multirow{15}{*}{ Subject field } & Classroom teacher & 69 & 33 \\
\hline & Mathematics & 34 & 16 \\
\hline & English & 22 & 11 \\
\hline & Science & 14 & 7 \\
\hline & Special education & 10 & 5 \\
\hline & Turkish Language & 10 & 5 \\
\hline & Social Studies & 9 & 4 \\
\hline & Guidance & 8 & 4 \\
\hline & Information technologies & 8 & 4 \\
\hline & Physical Education & 8 & 4 \\
\hline & Visual Arts & 6 & 3 \\
\hline & Music & 4 & 2 \\
\hline & Vocational teaching & 4 & 2 \\
\hline & Religious & 3 & 1 \\
\hline & Total & 209 & 100 \\
\hline \multirow{2}{*}{\multicolumn{2}{|c|}{ Professional seniority }} & Mean (Min.-Max.) & $\mathrm{Sd}$ \\
\hline & ority & $13.04(1-35)$ & 6.20 \\
\hline
\end{tabular}

When Table 1 is examined, it is seen that 113 (54\%) of the teachers participating in the study were female and 96 (46\%) were male; 76 (36\%) of them were working at primary schools, 101 (48\%) at secondary schools, and $32(15 \%)$ at high schools. It is also understood that they worked in various subject fields of teaching and the average of their professional seniority is 13.04 years $(\mathrm{Sd}=6.2)$.

\section{Instruments}

Classroom Management Styles Scale: The first scale used in the study is the "Classroom Management Styles Scale" (CMSS), which was developed by Bosworth (1997) and adapted into Turkish by Aktan and Sezer (2018). Developed as a 5-point Likert scale, CMSS consists of 12 items. The Cronbach Alpha internal consistency coefficient of the overall scale was estimated .82, and the coefficients for the sub-dimensions ranged between .69 and .71. Regarding the construct validity of the scale, Exploratory Factor Analysis (EFA) was performed first, followed by a Confirmatory Factor Analysis (CFA) to test the goodness of fit of the model obtained. The EFA results suggested that the twelve-item scale consists of four factors (authoritarian, authoritative, Laissez-faire, and irrelevant), which explained $66.68 \%$ of the total variance. The 
factor loadings ranged between .760 and .865 . In the CFA analysis, it was determined that the factor loads of the scale were high with low error variances, and the goodness of fit indices were excellent $\left(X^{2} / d f=115.05 / 48=2.39, p=0.00 ; R M S E A=.068 ; C F I=1.00 ; G F I=.99, N N F I=1.00\right)$.

Communication Skills Scale-Adult Form (CSS-AF): The second scale used in the study was Communication Skills Scale-Adult Form (CSS-AF). The 25 -item Communication Skills Scale (CCS) developed by Korkut-Owen and Bugay (2014) to measure communication skills can also be used for high school students (Bugay \& Korkut-Owen, 2016). An adaptation study was carried out by Korkut Owen and Demirbas-Celik (2017) so that the scale can also be used for adults. In order to test the construct validity of the scale, a total of 187 adults (aged between 22-46) were administered the scale. Exploratory Factor Analysis was conducted to test the factor structure of the scale. Principal Components Analysis was performed using the equamax rotation method. Result of the KMO test performed before the analysis was 0.927 and the Bartlett test result was 3358.412. As a result of the analysis, it was understood that the scale had a five-factor construct for adults and the scale explained $71.93 \%$ of the variance. The naming of the factors was done similar to the CSS form developed for high school and university students. The first factor consisting of nine items was named as Basic Skills and Self-Expression, the second factor with five items was named as Caring Communication, the third factor with three items was named as Willingness to Communicate, the fourth factor with five items was named as Active Listening and Non-verbal Communication; and the fifth factor with three items was named Complying with Communication Principles. As a result of the confirmatory factor analysis, it was seen that the goodness of fit statistics of the five-factor model for the 25 items were acceptable $\left[\chi^{2}(216)=242.0, p<0.001 ; \chi^{2} /\right.$ df- ratio $=2.45 ; C F I=0.91, I F I=0.91, R M S E A=0.87$, SRMR $\left.=0.008\right]$. Cronbach Alpha coefficient was calculated for the internal consistency reliability of the scale and it was found .94. Internal consistency coefficients for the individual factors of the scale were .95 for Basic Skills and Self-Expression factor, 81 for Caring Communication factor, .74 for Willingness to Communicate factor, .76 for Active Listening and Non-verbal Communication factor, and .65 for Complying with Communication Principles factor.

\section{Data analysis}

In the present study, it was aimed to test the predictors of teachers' classroom management styles using a set of multiple regression analyses. Based on the theoretical background the quantitative predictors were designated as the factors of teachers' communication skills scale including Basic Skills and Self-Expression, Caring Communication, Willingness to Communicate, Active Listening and Non-verbal Communication, and Complying with Communication Principles; and teachers' professional seniority. In addition, teacher's gender and the school stage at which the teacher is currently teaching were involved in the regression model as dummy variables, where women and primary school were taken as reference levels, respectively.

Prior to the regression analyses, assumptions of lack of outliers, linearity, normality of residuals and homogeneity of residual variances and lack of multicollinearity (Field, 2009; Pall ant, 2016; Tabachnick \& Fidell, 2007) were checked. The results of the assumption checks for each regression analysis were reported in the results section.

\section{RESULTS}

The research aimed to investigate teachers' classroom management styles and communication skills first. The results of the descriptive statistics about participating teachers' classroom management styles and communication skills are presented in table 2. 
Table 2. Statistics about teachers' classroom management styles and communication skills

\begin{tabular}{|c|c|c|c|c|c|}
\hline Variables & $\mathbf{N}$ & Mean & Sd & Min. & Max. \\
\hline \multicolumn{6}{|l|}{ Classroom Management Style } \\
\hline Authoritative & 209 & 4,36 & 0,62 & 2 & 5 \\
\hline Authoritarian & 209 & 3,21 & 0,7 & 1,33 & 5 \\
\hline Laissez-faire & 209 & 3,09 & 0,75 & 1 & 5 \\
\hline Indifferent & 209 & 2,18 & 0,77 & 1 & 5 \\
\hline \multicolumn{6}{|l|}{ Communication Skills } \\
\hline Basic Skills and Self-Expression & 209 & 4,28 & 0,44 & 2 & 5 \\
\hline Caring Communication & 209 & 4,34 & 0,49 & 2 & 5 \\
\hline Willingness to Communicate & 209 & 4,13 & 0,68 & 2,33 & 5 \\
\hline Active Listening and Non-verbal & 209 & 4,34 & 0,55 & 1,8 & 5 \\
\hline \multicolumn{6}{|l|}{ Communication } \\
\hline Complying with Communication Principles & 209 & 4,19 & 0,63 & 1,67 & 5 \\
\hline
\end{tabular}

As it is seen in Table 2, it was understood that classroom management styles participating teachers preferred the most were Authoritative (mean $=4.36)$, Authoritarian (mean $=3.21$ ) and Laissez-faire (mean $=3.09$ ) styles, respectively, and Indifferent (mean $=2.18$ ) management style was the least used one. When teachers' views on the factors of communication skills were examined, it was found that the highest scores were taken from the Caring Communication (mean= 4.34) and Active Listening and Non-verbal Communication (mean= 4.34) factors of the scale, and they were followed by Basic Skills and Self-Expression (mean= 4.28), Complying with Communication Principles (mean= 4.19), and Willingness to Communicate (mean= 4.13).

Before the regression analysis, the correlations between the quantitative predictors (teachers' professional seniority, and factors of teachers' communication skills scale: Basic Skills and SelfExpression, Caring Communication, Willingness to Communicate, Active Listening and Nonverbal Communication, and Complying with Communication Principles) were analysed, the results of which are presented in table 3 below:

Table 3. Correlations between the quantitative predictors and outcome variable

\begin{tabular}{|c|c|c|c|c|c|c|c|c|c|c|}
\hline Variables & & 1 & 2 & 3 & 4 & 5 & 6 & 7 & 8 & 9 \\
\hline 1. Professional & $\mathrm{r}$ & & & & & & & & & \\
\hline Seniority & $\begin{array}{l}\mathrm{p} \\
\mathrm{n}\end{array}$ & & & & & & & & & \\
\hline 2. CSS: Basic & $r$ & 0.03 & & & & & & & & \\
\hline Skills and Self- & $\mathrm{p}$ & 0.697 & & & & & & & & \\
\hline Expression & $\mathrm{n}$ & 209 & & & & & & & & \\
\hline 3. CSS: Caring & $r$ & -0.08 & $0.72^{* * *}$ & & & & & & & \\
\hline Communication & $\mathrm{p}$ & 0.253 & $<.001$ & & & & & & & \\
\hline & $\mathrm{n}$ & 209 & 209 & & & & & & & \\
\hline 4. CSS: & $r$ & 0.01 & $0.58^{* * *}$ & $0.39 * * *$ & & & & & & \\
\hline Willingness to & $\mathrm{p}$ & 0.836 & $<.001$ & $<.001$ & & & & & & \\
\hline Communicate & $\mathrm{n}$ & 209 & 209 & 209 & & & & & & \\
\hline 5. CSS: Active & $r$ & -0.00 & $0.68 * * *$ & $0.65 * * *$ & $0.61 * * *$ & & & & & \\
\hline Listening and & $\mathrm{p}$ & 0.981 & $<.001$ & $<.001$ & $<.001$ & & & & & \\
\hline $\begin{array}{l}\text { Non-verbal } \\
\text { Communication }\end{array}$ & $n$ & 209 & 209 & 209 & 209 & & & & & \\
\hline 6. CSS: & $r$ & 0.07 & $0.58^{* * *}$ & $0.58 * * *$ & $0.51^{* * *}$ & $0.57^{* * *}$ & & & & \\
\hline Complying with & $\mathrm{p}$ & 0.295 & $<.001$ & $<.001$ & $<.001$ & $<.001$ & & & & \\
\hline $\begin{array}{l}\text { Communication } \\
\text { Principles }\end{array}$ & $n$ & 209 & 209 & 209 & 209 & 209 & & & & \\
\hline 7. CMS: & $r$ & $-0.17^{*}$ & 0.03 & 0.04 & -0.05 & 0.07 & 0.03 & & & \\
\hline Authoritarian & $\mathrm{p}$ & 0.016 & 0.664 & 0.570 & 0.484 & 0.307 & 0.661 & & & \\
\hline
\end{tabular}




\begin{tabular}{|c|c|c|c|c|c|c|c|c|c|c|}
\hline \multirow{4}{*}{$\begin{array}{l}\text { 8. CMS: } \\
\text { Authoritative }\end{array}$} & $\mathrm{n}$ & 209 & 209 & 209 & 209 & 209 & 209 & & & \\
\hline & $r$ & -0.05 & $0.37 * * *$ & $0.29 * * *$ & $0.27 * * *$ & $0.34^{* * *}$ & $0.23^{* * *}$ & -0.03 & & \\
\hline & $\mathrm{p}$ & 0.436 & $<.001$ & $<.001$ & $<.001$ & $<.001$ & $<.001$ & 0.632 & & \\
\hline & $\mathrm{n}$ & 209 & 209 & 209 & 209 & 209 & 209 & 209 & & \\
\hline \multirow{3}{*}{$\begin{array}{l}\text { 9. CMS: Laissez- } \\
\text { faire }\end{array}$} & $r$ & -0.00 & $0.15 *$ & 0.08 & $0.16^{*}$ & 0.07 & 0.05 & -0.01 & 0.08 & \\
\hline & $\mathrm{p}$ & 0.964 & 0.025 & 0.251 & 0.019 & 0.339 & 0.438 & 0.860 & 0.236 & \\
\hline & $n$ & 209 & 209 & 209 & 209 & 209 & 209 & 209 & 209 & \\
\hline \multirow{3}{*}{$\begin{array}{l}\text { 10. CMS: } \\
\text { Indifferent }\end{array}$} & $r$ & -0.03 & $-0.15 *$ & -0.07 & 0.03 & $-0.14^{*}$ & -0.05 & -0.04 & -0.03 & $0.22 * *$ \\
\hline & $\mathrm{p}$ & 0.617 & 0.032 & 0.308 & 0.665 & 0.049 & 0.484 & 0.543 & 0.640 & 0.001 \\
\hline & $\mathrm{n}$ & 209 & 209 & 209 & 209 & 209 & 209 & 209 & 209 & 209 \\
\hline
\end{tabular}

CSS: Communication Skills Scale, CMS: Classroom Management Style, Note: ${ }^{*} \mathrm{p}<.05,{ }^{* *} \mathrm{p}<.01, * * * \mathrm{p}<.001$

In Table 3, it is seen that regarding the relationship of teachers' professional seniority with communication skills and classroom management styles, there was only a low level of negative correlation ( $r=-0.17, p<.05)$ between teachers' professional seniority and the "Authoritarian" classroom management style. On the other hand, there is a high level of positive relationship between "Basic Skills and Self-Expression" and "Caring Communication" ( $r=0.72, p<.001)$. Positive relationships were found between the authoritative style of classroom management and all dimensions of the communication skills scale ranging between low and medium levels $(r=0.37, r=0.29, r=0.27, r=0.34, r=0.23, p<.001)$. In addition, there were low levels of positive correlations between the Laissez-faire style of classroom management and Basic Skills and SelfExpression $(r=0.15, p<.05)$ dimension and Willingness to Communicate $(r=0.16, p<.05)$ dimension of the communication skills scale. Finally, there were low levels of negative correlations between the Indifferent style of classroom management and Basic Skills and SelfExpression ( $r=-0.15, p<.05)$ dimension and Active Listening and Non-verbal Communication ( $r=-$ $0.14, p<.05)$ dimension of the communication skills scale.

In order to assess whether teachers' communication skills (Basic Skills and Self-Expression, Caring Communication, Willingness to Communicate, Active Listening and Non-verbal Communication, and Complying with Communication Principles), their professional seniority, gender, and school stage significantly predict their level of Authoritative classroom management style, a multiple linear regression analysis was done. Prior to the analysis assumptions of lack of outliers, linearity, normality of residuals and homogeneity of residual variances and lack of multicollinearity were checked. Accordingly, since maximum Cook's distance was $0.06(<1)$ and standardized residuals ranged between \pm 3.3 , no outliers were detected. The linearity of the relationships between the predictor variables and the Authoritative classroom management style was examined using scatterplots and correlation analysis, and it was seen that, except for professional seniority ( $r=-0.05, p>.0 .05)$, Authoritative classroom management style was significantly correlated with the predictors regarding

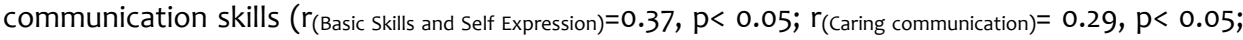
$r_{\text {(Willingness to communicate) }}=0.27, p<0.05 ; r_{\text {(Active Listening and Non-verbal Communication) }}=0.34, p<0.05 ; r_{\text {(Complying }}$ with Communication Principles) $=0.23, p<0.05)$. Since the Shapiro-Wilk normality of residuals test was non-significant ( $W=0.96, p>0.05)$ and the residuals were distributed within \pm 3 intervals on the $\mathrm{Q}-\mathrm{Q}$ plot, residuals were considered to distribute normally. Moreover, as the residual plots were scattered randomly, residual variances were considered to be homogeneous. Finally, the highest correlation between the predictor variables was $r_{\text {(Basic Skills and Self Expression-Caring Communication) }}$ $=0.72$, and the VIF values were less than 10 and the tolerance values were greater than 0.2 , which indicated no multicollinearity issue. The results of Multiple linear regression analysis testing the predictors of teachers' level of Authoritative CMS are given in table 4 . 
Table 4. Multiple linear regression analysis results for teachers' level of Authoritative CMS

\begin{tabular}{|c|c|c|c|c|c|}
\hline Predictors & $\mathrm{B}$ & $\mathrm{Se}_{\mathrm{e}}$ & $\beta$ & $\mathrm{t}$ & $p$ \\
\hline Intercept & 1.98 & 0.47 & & 4.18 & $<.001$ \\
\hline Basic Skills and Self-Expression & 0.39 & 0.16 & 0.26 & 2.46 & $0.015^{*}$ \\
\hline Caring Communication & -0.03 & 0.14 & -0.02 & -0.23 & 0.815 \\
\hline Willingness to Communicate & 0.01 & 0.08 & 0.01 & 0.14 & 0.889 \\
\hline $\begin{array}{l}\text { Active Listening and Non-verbal } \\
\text { Communication }\end{array}$ & 0.26 & 0.12 & 0.22 & 2.20 & $0.029 *$ \\
\hline Complying with Communication Principles & -0.07 & 0.09 & -0.07 & -0.74 & 0.461 \\
\hline $\begin{array}{l}\text { Professional Seniority } \\
\text { Gender: }\end{array}$ & -0.01 & 0.01 & -0.07 & -0.94 & 0.348 \\
\hline $\begin{array}{l}\text { Men - Women } \\
\text { School stage: }\end{array}$ & 0.07 & 0.09 & 0.12 & 0.82 & 0.415 \\
\hline Middle - Primary & 0.07 & 0.09 & 0.11 & 0.70 & 0.486 \\
\hline High - Primary & -0.06 & 0.13 & -0.09 & -0.43 & 0.670 \\
\hline$R^{2}=0.16$ & & & & & \\
\hline$p<0.05$ & & & & & \\
\hline
\end{tabular}

As a result of the multiple linear regression analysis, it was found that the designated predictors altogether significantly predicted teachers' level of Authoritative classroom management style $\left(R=0.40, F_{(9,199)}=4.13, P<.05\right)$. The model as a whole explained $16 \%$ of the total variance in the teachers' scores from Authoritative classroom management style factor. From the significance of the regression coefficients, it was seen that only Basic Skills and Self-Expression $(\beta=0.26, p$ $<0.05)$ and Active Listening and Non-verbal Communication $(\beta=0.22, p<0.05)$ variables were significant predictors of Authoritative classroom management scores, respectively; however, other factors were not significant predictors of Authoritative classroom management scores ( $p>0.05$ ). Considering the positive and moderate correlation between teachers' level of Authoritative classroom management style and Basic Skills and Self-Expression $(r=0.37, p<$ 0.05 ), it can be said that as the teachers basic communications skills and their ability to express themselves increase they tend to adopt a more authoritative classroom management style. Likewise, considering the positive and moderate correlation between teachers' level of Authoritative classroom management style and Active Listening and Non-verbal Communication $(r=0.34, p<0.05)$ it can be said that when the teachers' are more skilful in terms of active listening and use of body language, they tend to adopt a more authoritative classroom management style.

In order to assess whether teachers' communication skills (Basic Skills and Self-Expression, Caring Communication, Willingness to Communicate, Active Listening and Non-verbal Communication, and Complying with Communication Principles), their professional seniority, gender, and school stage significantly predict their level of Authoritarian classroom management style, a second multiple linear regression analysis was done. Prior to the analysis assumptions of lack of outliers, linearity, normality of residuals and homogeneity of residual variances and lack of multicollinearity were checked. Accordingly, since maximum Cook's distance was $0.07(<1)$ and standardized residuals ranged between \pm 3.3 , no outliers were detected. The linearity of the relationships between the predictor variables and the Authoritarian classroom management style was examined using scatterplots and correlation analysis, and it was seen that, except for professional seniority ( $r=-0.17, p<.0 .05)$, Authoritarian classroom management style was not significantly correlated with the predictors regarding communication skills ( $p>0.05$ ). Since the Shapiro-Wilk normality of residuals test was nonsignificant $(W=0.98, p>0.05)$ and the residuals were distributed within \pm 3 intervals on the $Q-Q$ plot, residuals were considered to distribute normally. Moreover, as the residual plots were 
scattered randomly residual variances were considered to be homogeneous. Finally, the highest correlation between the predictor variables was $r$ (Basic Skills and Self Expression-Caring Communication) $=0.72$, and the VIF values were less than 10 and the tolerance values were greater than 0.2 , which indicated no multicollinearity issue. The results of Multiple linear regression analysis testing the predictors of teachers' level of Authoritarian classroom management style are given in table 5.

Table 5. Multiple linear regression analysis results for teachers' level of Authoritarian CMS

\begin{tabular}{|c|c|c|c|c|c|}
\hline Predictors & $\mathrm{B}$ & $\mathrm{S}_{\mathrm{e}}$ & $\beta$ & $\mathrm{t}$ & $\mathrm{p}$ \\
\hline Intercept & 3.48 & 0.51 & & 6.81 & $<.001$ \\
\hline Basic Skills and Self-Expression & 0.08 & 0.18 & 0.05 & 0.44 & 0.663 \\
\hline Caring Communication & -0.11 & 0.16 & -0.08 & -0.69 & 0.489 \\
\hline Willingness to Communicate & -0.16 & 0.10 & -0.16 & -1.70 & 0.091 \\
\hline $\begin{array}{l}\text { Active Listening and Non-verbal } \\
\text { Communication }\end{array}$ & 0.19 & 0.14 & 0.15 & 1.42 & 0.158 \\
\hline Complying with Communication Principles & 0.04 & 0.11 & 0.04 & 0.38 & 0.703 \\
\hline Seniority & -0.03 & 0.01 & -0.23 & -3.06 & $0.003 *$ \\
\hline Gender: & & & & & \\
\hline Men - Women & 0.18 & 0.10 & 0.25 & 1.69 & 0.093 \\
\hline School stage: & & & & & \\
\hline Middle - Primary & -0.11 & 0.11 & -0.15 & -0.96 & 0.338 \\
\hline High - Primary & 0.09 & 0.15 & 0.13 & 0.59 & 0.557 \\
\hline$R^{2}=0.07$ & & & & & \\
\hline$p>0.05$ & & & & & \\
\hline
\end{tabular}

As a result of the multiple linear regression analysis, it was found that the designated predictors did not significantly predict teachers' level of Authoritarian classroom management style ( $R=$ $\left.0.27, F_{(9,199)}=1.69, p>.05\right)$. Though the model as a whole was not significant, when other variables were controlled, only Professional Seniority $(\beta=-0.23, p<0.05)$ was a significant predictor of teachers' level of Authoritarian classroom management in a negative direction. Considering the negative and small correlation between professional seniority and teachers' level of Authoritarian classroom management style $(r=-0.17, p<0.05)$, it can be said that as the teachers' professional seniority increase, i.e. get more experienced, they tend to adopt a less authoritarian classroom management style.

In order to assess whether teachers' communication skills (Basic Skills and Self-Expression, Caring Communication, Willingness to Communicate, Active Listening and Non-verbal Communication, and Complying with Communication Principles), their professional seniority, gender, and school stage significantly predict their level of Laissez-faire classroom management style, a third multiple linear regression analysis was done. Prior to the analysis assumptions of lack of outliers, linearity, normality of residuals and homogeneity of residual variances and lack of multicollinearity were checked. Accordingly, since maximum Cook's distance was $0.07(<1)$ and standardized residuals ranged between \pm 3.3 , no outliers were detected. The linearity of the relationships between the predictor variables and the Laissez-faire classroom management style was examined using scatterplots and correlation analysis, and it was seen that, except for Basic Skills and Self-Expression $(r=0.15, p<0.05)$ and Willingness to Communicate $(r=0.16$, $p<0.05$ ), Laissez-faire classroom management style was not significantly correlated with any of the other quantitative predictors ( $p>0.05$ ). Since the Shapiro-Wilk normality of residuals test was non-significant $(\mathrm{W}=0.99, \mathrm{p}>0.05)$ and the residuals were distributed within \pm 3 intervals on the Q-Q plot, residuals were considered to distribute normally. Moreover, as the residual plots were scattered randomly residual variances were considered to be homogeneous. Finally, the highest correlation between the predictor variables was $r_{\text {(Basic Skills and Self Expression - Caring Communication) }}$ 
$=0.72$, and the VIF values were less than 10 and the tolerance values were greater than 0.2 , which indicated no multicollinearity issue. The results of Multiple linear regression analysis testing the predictors of teachers' level of Laissez-faire classroom management style are given in table 6.

Table 6. Multiple linear regression analysis results for teachers' level of Laissez-faire CMS

\begin{tabular}{|c|c|c|c|c|c|}
\hline Predictors & B & $\mathrm{S}_{\mathrm{e}}$ & $\beta$ & $\mathbf{t}$ & $\mathrm{p}$ \\
\hline Intercept & 2.04 & 0.55 & & 3.73 & $<.001$ \\
\hline Basic Skills and Self-Expression & 0.28 & 0.20 & 0.17 & 1.42 & 0.156 \\
\hline Caring Communication & -0.02 & 0.17 & -0.01 & -0.09 & 0.927 \\
\hline Willingness to Communicate & 0.19 & 0.11 & 0.18 & 1.84 & 0.067 \\
\hline $\begin{array}{l}\text { Active Listening and Non-verbal } \\
\text { Communication }\end{array}$ & -0.14 & 0.15 & -0.10 & -0.95 & 0.342 \\
\hline Complying with Communication Principles & -0.05 & 0.12 & -0.04 & -0.41 & 0.684 \\
\hline $\begin{array}{l}\text { Professional Seniority } \\
\text { Gender: }\end{array}$ & -0.00 & 0.01 & -0.00 & -0.05 & 0.963 \\
\hline $\begin{array}{l}\text { Men - Women } \\
\text { School stage: }\end{array}$ & -0.01 & 0.11 & -0.02 & -0.12 & 0.908 \\
\hline $\begin{array}{l}\text { Middle - Primary } \\
\text { High - Primary }\end{array}$ & $\begin{array}{l}-0.05 \\
-0.26\end{array}$ & $\begin{array}{l}0.12 \\
0.17\end{array}$ & $\begin{array}{l}-0.06 \\
-0.35\end{array}$ & $\begin{array}{l}-0.40 \\
-1.58\end{array}$ & $\begin{array}{l}0.692 \\
0.116\end{array}$ \\
\hline $\begin{array}{ll}R=0.24 & R^{2}=0.06 \\
F=1.31 & p>0.05\end{array}$ & & & & & \\
\hline
\end{tabular}

As a result of the multiple linear regression analysis, it was found that the designated predictors did not significantly predict teachers' level of Laissez-faire classroom management style $(R=$ $\left.0.24, F_{(9,199)}=1.31, p>.05\right)$. It was also understood that, when other variables were controlled, significantly correlated variables ( $r_{\text {(Basic Skills and Self-Expression) }}=0.15, p<0.05$ and $r_{\text {(Willingness to }}$ Communicate) $=0.16, p<0.05)$ turned out to be insignificant predictors of Laissez-faire classroom management style.

Finally, in order to assess whether teachers' communication skills (Basic Skills and SelfExpression, Caring Communication, Willingness to Communicate, Active Listening and Nonverbal Communication, and Complying with Communication Principles), their professional seniority, gender, and school stage significantly predict their level of Indifferent classroom management style, a fourth multiple linear regression analysis was done. Prior to the analysis assumptions of lack of outliers, linearity, normality of residuals and homogeneity of residual variances and lack of multicollinearity were checked. Accordingly, since maximum Cook's distance was $0.09(<1)$ and standardized residuals ranged between \pm 3.3 , no outliers were detected. The linearity of the relationships between the predictor variables and the Indifferent classroom management style was examined using scatterplots and correlation analysis, and it was seen that, except for Basic Skills and Self-Expression $(r=-0.15, p<0.05)$ and Active Listening and Non-verbal Communication ( $r=-0.14, p<0.05)$, Indifferent classroom management style was not significantly correlated with any of the other quantitative predictors $(p>0.05)$. Since the Shapiro-Wilk normality of residuals test was non-significant $(W=0.97, p>0.05)$ and the residuals were distributed within \pm 3 intervals on the Q-Q plot, residuals were considered to distribute normally. Moreover, as the residual plots were scattered randomly residual variances were considered to be homogeneous. Finally, the highest correlation between the predictor

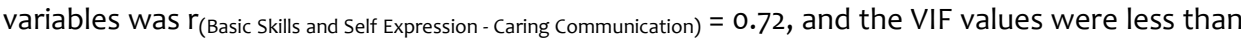
10 and the tolerance values were greater than 0.2 , which indicated no multicollinearity issue. The results of Multiple linear regression analysis testing the predictors of teachers' level of Indifferent classroom management style are given in table 7. 
Table 7. Multiple linear regression analysis results for teachers' level of Indifferent CMS

\begin{tabular}{|c|c|c|c|c|c|}
\hline Predictors & $\mathrm{B}$ & $\mathrm{S}_{\mathrm{e}}$ & $\beta$ & $\mathrm{t}$ & $\mathrm{p}$ \\
\hline Intercept & 3.09 & 0.55 & & 5.57 & $<.001$ \\
\hline Basic Skills and Self-Expression & -0.46 & 0.20 & -0.27 & -2.31 & $0.022 *$ \\
\hline Caring Communication & 0.21 & 0.17 & 0.13 & 1.21 & 0.228 \\
\hline Willingness to Communicate & 0.29 & 0.11 & 0.25 & 2.72 & $0.007 *$ \\
\hline $\begin{array}{l}\text { Active Listening and Non-verbal } \\
\text { Communication }\end{array}$ & -0.26 & 0.15 & -0.19 & -1.73 & 0.085 \\
\hline Complying with Communication Principles & 0.04 & 0.12 & 0.03 & 0.32 & 0.746 \\
\hline $\begin{array}{l}\text { Professional Seniority } \\
\text { Gender: }\end{array}$ & -0.00 & 0.01 & -0.02 & -0.28 & 0.782 \\
\hline $\begin{array}{l}\text { Men - Women } \\
\text { School stage: }\end{array}$ & 0.03 & 0.11 & 0.04 & 0.25 & 0.803 \\
\hline Middle - Primary & -0.01 & 0.12 & -0.01 & -0.05 & 0.962 \\
\hline High - Primary & -0.30 & 0.17 & -0.39 & -1.80 & 0.074 \\
\hline $\begin{array}{l}R^{2}=0.08 \\
p<0.05\end{array}$ & & & & & \\
\hline
\end{tabular}

* $p<0.05$

As a result of the multiple linear regression analysis, it was found that the designated predictors altogether significantly predicted teachers' level of Indifferent classroom management style ( $R$ $\left.=0.29, F_{(9,199)}=1.99, p<.05\right)$. The model as a whole explained $8 \%$ of the total variance in the teachers' scores from Indifferent classroom management style factor. From the significance of the regression coefficients, it was seen that only Basic Skills and Self-Expression $(\beta=-0.27, p$ $<0.05)$ and Willingness to communicate $(\beta=0.25, p<0.05)$ variables were significant predictors of Indifferent classroom management scores, respectively; however, other factors were not significant predictors of indifferent classroom management scores ( $p>0.05)$. Considering the negative and small correlation between teachers' level of indifferent classroom management style and Basic Skills and Self-Expression $(r=-0.15, p<0.05)$ it can be said that as the teachers' basic communications skills and their ability to express themselves increase they tend to adopt a less indifferent classroom management style. On the other hand, it was also understood that, although willingness to communicate was non-significantly correlated with indifferent classroom management style $(r=0.03, p>0.05)$, when other variables were controlled, it turned out to be a significant and positive predictor of indifferent classroom management style. Accordingly, it can be said that as the teachers' willingness to communicate increase they tend to adopt a more indifferent classroom management style.

Also, to note, despite the initial significant zero-order correlation $(r=-0.14, p<0.05)$, Active Listening and Non-verbal Communication skill turned out to be a non-significant predictor, when other variables were controlled.

\section{DISCUSSION AND CONCLUSION}

Factors such as curricula or quality of teacher on their own are not sufficient for a student to learn meaningfully and achieve academic success, but the interactive processes and classroom management play a very central role, as well (Barroso \& Dias, 2020; Djigic \& Stojiljkovic, 2011). Understanding a teacher's classroom management style and communication skills is extremely important in preventing undesired behaviours in the classroom (Dunbar, 2004). It can be said that the teachers apply different communication techniques and classroom management styles, which differ according to their attitudes towards student development and learning, and each of which can have different effects on students (Moradi, 2020). In this context, it was aimed to test communication skills as predictors of teachers' classroom management styles, as 
well as the variables of professional seniority, school stage and gender, which were considered to be significant predictors of classroom management styles.

When the teachers' levels of classroom management style scores were examined, it was determined that the most preferred classroom management style was Authoritative style, followed by Authoritarian and Laissez-faire styles, respectively, and the least used classroom management style was Indifferent. From this, it can be said that participating teachers attach importance to the feelings, thoughts and motivation of the students in the classroom environment and they support the positive classroom climate. It is possible to come across studies with similar results in the literature. For example, Yilmaz (2009) found that primary school teachers mostly use Authoritative classroom management style, followed by Authoritarian, Laissez-faire and Indifferent styles, respectively. Abu-Tineh, Khasawneh, \& Khalaileh, (2011), in their study examining the classroom management styles of teachers working in Jordanian schools, revealed that teachers generally preferred the authoritative classroom management approach. Barni, Russo \& Danioni (2018), in their study examining teachers 'understanding of individual and social values as predictors of classroom management styles, revealed that there was a relationship between teachers' understanding of value and classroom management styles, and determined that authoritative and authoritarian management styles were preferred more than other styles. In their study examining the relationship between pre-service teachers' multicultural education attitudes and classroom management styles, Debbag and Fidan (2020) found that the participants generally adopted an authoritarian classroom management style, however, they also determined that they have positive attitudes towards multicultural and democracy education. Although it is seen that authoritarian and authoritative classroom management styles are widely preferred, there are also studies showing that the Laissez-faire management style is also predominantly preferred by teachers (Aytac \& Uyangor, 2020; Ekici, 2004; Sezer, Aktan, Tezci, \& Erdener, 2017).

When teachers' views on the factors of communication skills were examined, it was found that the highest scores were taken from the Caring Communication and Active Listening and Nonverbal Communication factors of the scale, and they were followed by Basic Skills and SelfExpression, Complying with Communication Principles, and Willingness to Communicate. In general, it can be said that the communication skills of the teachers are high. There are studies in the literature that reported similar results. In their study examining the communication skills of middle school teachers, Kadıoglu Ates and Bulut (2019) found that the mean scores of the dimensions of "Basic Skills and Self-Express", "Willingness to Communicate" and "Complying with Communication Principles" were "high"; and mean scores of the "Caring Communication" and "Active Listening and Non-verbal Communication factors" dimensions were "very high". Toluc (2020), on the other hand, found that university students believe they have very high levels of communication skills ranking in the order of "Communication Principles and Basic Skills", "Active Listening and Non-verbal communication", "Willingness to Communicate" and "Self-Expression". Apart from these studies, there are studies with similar findings (Arslanhan, 2020; Cetinkaya, 2011; Gun, 2018).

Another finding of the study is that there was a significant relationship, albeit at low levels, between teachers' professional seniority and "authoritarian" classroom management style. Similarly, Laut (1999) tested the hypothesis that more experience in teaching would be associated with less interventionist classroom management styles, and found that teachers with moderate experience had a more interventionist style than experienced teachers. On the other hand, Gulec and Durmus (2019) revealed that teachers adopt a more laissez-faire classroom management style as their professional seniority increases. There are other studies suggesting that with increased professional seniority, teachers use less interventionist, more 
authoritative and laissez-faire classroom management styles are preferred (Bas, 2019; Buyuktaskapu Soydan et al., 2018; Ersen \& Kan, 2019; Pektas \& Saygili, 2010; Talsik, 2015). It is extremely important which classroom management style is preferred by teachers, since adopting a more laissez-faire and interactive classroom management style will also positively affect student success in a classroom climate where teacher and student interaction is good (Djigic \& Stojiljkovic, 2011). In parallel with some research findings, there are studies revealing that gender and school stage variables are not associated with teachers' communication skills and classroom management styles (Bas, 2019; Sahin, 2015). On the contrary, there are studies finding that these variables are associated with teachers' classroom management styles (Hoon, Nasaruddin, \& Singh, 2017; Ihtiyaroglu, 2018; Karakaya \& Mumin, 2018).

Another finding of the study is that as teachers' Basic Skills and Self-Expression skills and Active Listening and Non-verbal Communication skills increase, they tend to adopt a more Authoritative classroom management style. The classroom management profile of teachers is determined by the behaviours they show in the process of communicating with their students (Yurtal \& Yasar, 2018), and the teachers' ability to communicate effectively with students, teach them internal control skills, minimize classroom problems, and increase the efficiency of teaching are the basic competencies that stand out in classroom management (Gursimsek, 1999). In this respect, it can be said that these characteristics that teachers exhibit within the scope of communication skills are effective in the formation of an authoritative classroom management style.

Another finding of the study was that teachers' communication skills, gender, professional seniority, and the school stage were not significant as predictors of Laissez-faire classroom management style. There are some findings in the literature that may be related to the present research findings. For example, Yilmaz (2009) found a low-level of negative relationship between the classroom teachers' laissez-faire classroom management styles and student control ideologies. The researcher concluded that where teachers' views on student control ideologies are concentrated, the laissez-faire classroom management style is also less preferred. Sadik (2016) could not find any significant relationship between the primary school teachers' laissez-faire classroom management style and their age, the faculty they graduated from, in-service training background, class size, and grade level variables. Although the laissezfaire classroom management style gives the student a large range of action to make them feel independent, it has controversial aspects in that the teachers demand not much effort from the students, avoid taking responsibility as much as possible, and leave the decisions to the student. Another important finding of the study was that teachers adopt indifferent classroom management style less when their basic communication skills and ability to express themselves increase, and as their willingness to communicate increases, they tend to adopt a more indifferent classroom management style. As expected, when teachers communicate better and express themselves better, they can reasonably adopt less "indifferent classroom management style". However, it is noteworthy that they tend to adopt "indifferent classroom management style" when they are more willingness to communicate. This suggests that teacher's willingness to communicate cause a deviation from learning and leads the students to going through the motions and killing time (Bosworth, 1997). As for the gender of the teachers as non-significant predictor of the indifferent classroom management style, Sezer, Aktan, Tezci, and Erdener (2017) also found that there is no significant difference between the teachers' use of indifferent classroom management styles in terms of gender variable. However, contrary to the finding about school stage in the present study, they found that high school teachers use more indifferent classroom management strategies than primary school teachers do.

In fact, the communication skills of teachers and the classroom management styles they use are affected and shaped by many factors such as the personal characteristics of the teacher, 
and the peculiarities of the classroom and school environment in which they work (Ekici, 2004). In this regard, it is extremely important that teachers, who have vital effects on students, have positive attitudes towards students, adopt management approaches that support students' development and learning, and reflect this on their classroom management styles. Therefore, pre- and post-service supportive studies can be conducted to support teachers' professional development especially in terms of communication skills and behavior management styles. In addition, the relationship between teachers' classroom management styles and communication skills can be examined using different data collection methods on different samples.

\section{References:}

Abu-Tineh, A. M., Khasawneh, S. A., \& Khalaileh, H. A. (2011). Teacher self-efficacy and classroom management styles in Jordanian schools. Management in Education, 25(4), 175181. doi:10.1177/0892020611420597.

Adedigba, O \& Sulaiman, F.R. (2020). Influence of teachers' classroom management style on pupils' motivation for learning and academic achievement in Kwara State. International Journal of Educational Methodology, 6(2), 471 - 480.

Aktan, S., \& Sezer, F. (2018). Investigating the psychometric characteristics of classroom management styles scale. Kastamonu Education Journal, 26(2), 439-449. doi:10.24106/kefdergi.389803.

Akuzum, C, Ozdemir Gultekin, S. (2017). The investigation of relationship between primary school teachers' communication skills and classroom management skills. Electronic Journal of Education Sciences, 6(12), 88-107.

Arslanhan, E. (2020). The investigation and comparison of the effective communication skills and the emotional intelligence of the students of the faculty of education receiving and not receiving music education (Doctoral dissertation). Turkish National Thesis Center. (Thesis no. 640865)

Barni, D., Russo, C., \& Danioni, F. (2018). Teachers' values as predictors of classroom management styles: a relative weight analysis. Frontiers in Psychology, 9, 1-5. https://doi.org/10.3389/fpsyg.2018.01970.

Barroso, R. \& Dias, D. (2020). Education never goes out of style: Classroom management styles under analysis, INTED2020 Proceedings, 2424-2432. Doi.10.21125/inted.2020.0741

Bas, K. (2019). The relationship between classroom management skills and self-confidence of social studies teachers. International Journal of Education \& Literacy Studies 7(4), 62-68. DOI: http://dx.doi.org/10.7575/aiac.ijels.v.7n.4p.62

Basar, H. (2004). Sinif yonetimi (11 ${ }^{\text {th }}$ Ed.) [Classroom management]. Ankara: Ani Yayinlari.

Berger, J. L. \& Girardet, C. (2020) Vocational teachers' classroom management style: The role of motivation to teach and sense of responsibility, European Journal of Teacher Education, 1-17. DOI: $10.1080 / 02619768.2020 .1764930$

Bosworth, K. (1997). What is your classroom management profile? Teacher Talk-A Publication for Secondary Education Teachers, 1(2). Retrieved January 24, 2021, from http://protectiveschools.org/drugstats/tt/v1i2/table.html.

Bugay, A. \& Korkut-Owen, F. (2016). Predictors of communication skills: information and communications technology usage, self-esteem, extraversion and gender. Mersin University Journal of the Faculty of Education, 12(2), 542-554.

Buyukozturk, S., Kilic Cakmak, E., Akgun, O.E., Karadeniz, S., \& Demirel, F. (2014). Bilimsel arastirma yontemleri (16th Ed.) [Scientific research methods]. Ankara: Pegem Yayinlari. 
Buyuktaskapu Soydan, S., Devlet Alakoc P., Ozturk Samur, A., \& Angin, D.E. (2018). Pre-school teachers' classroom management competency and the factors affecting their understanding of discipline. Eurasian Journal of Educational Research,73, 149-172.

Chambers, S., \& Hardy, J. (2005). Length of time in student teaching: effects on classroom control orientation and self-efficacy beliefs. Educational Research Quarterly, 28(3), 3-9.

Claro, M., Salinas, A., Cabello-Hutt, T., Martin, E. S., Preiss, D. D., Valenzuela, S., \& Jara, I. (2018). Teaching in a Digital Environment (TIDE): Defining and measuring teachers' capacity to develop students' digital information and communication skills. Computers \& Education, 121, 162-174. doi: https://doi.org/10.1016/j.compedu.2018.03.001

Crosbie-Burnett, M., \& Giles-Sims, J. (1994). Adolescent adjustment and stepparenting styles. Family Relations: An Interdisciplinary Journal of Applied Family Studies, 43(4), 394399. https://doi.org/10.2307/585370.

Cetinkaya, Z. (2011). Identifying Turkish pre-service teachers' views related to communication skills. Kastamonu Egitim Dergisi, 19 (2), 567-576.

Debbag, M. \& Fidan, M. (2020). Relationships between prospective teachers' multicultural education attitudes and classroom management styles. International Journal of Progressive Education, 16(2), 111-122.

Djigic, G. \& Stojiljkovic, S. (2011). Classroom management styles, classroom climate and school achievement. Procedia-Social and Behavioral Sciences. Procedia - Social and Behavioral Sciences, 29, 819-828. doi: 10.1016/j.sbspro.2011.11.310.

Doyle, W. (1980): Classroom management. West Lafayette, Ind: Kappa Delta Pi.

Dunbar, C. (2004). Best Practices in Classroom Management. Michigan: College of Education Michigan State University.

Durukan, E., and Maden, S. (2010). A Study on Communication Skills Of Turkish Teachers. Sosyal Bilimler Arastırmaları Dergisi, 5(1), 59-74.

Ekici, G. (2004). Assessment of teachers' classroom management profiles in first-level elementary education. Education and Science, 131, 50-60.

Emmer, E. T. \& Sabornie, E. J. (Eds.) (2015). Handbook of classroom management (2nd ed.). New York: Routledge.

Ersen, E. \& Kan, S. (2019). The role of socio-demographic factors of teachers' disciplines styles and classroom management approaches: A case study of teachers in ZeytinburnuIstanbul. Journal of Education and Training Studies, 7(10), 14-23. doi: 10.11114/jets.v7i10S.4454.

Evertson, C.M., \& Weinstein, C.S. (Eds.). (2006). Handbook of classroom management: Research, practice, and contemporary issues. New York: Routledge.

Field, A. (2009). Discovering Statistics Using IBM SPSS Statistics (3rd Edition). London: Sage Publication.

Gulec, S. ve Durmus, N. (2019). Examination of classroom management approaches of social studies teachers. International Education Studies, 12(11), 139-147. doi: 10.5539 /ies.v12 n11p139.

Gun, E. (2018). Communication skills of pre-service music teachers. Turkish Studies-Educational Sciences, 13(11), 615-622. http://dx.doi.org/10.7827/TurkishStudies.13450.

Gursimsek, I. (1999). Effective communication skills for effective classroom management. Educatioll and Science, 23(112), 40-44.

Guven, E., and Cevher, N. (2005). Okul oncesi ogretmenlerinin sinif yonetimi. Pamukkale Universitesi Egitim Fakultesi Dergisi, 18(18) , 71-92

Guzeldere Aydin, D. \& Ocak Karabay, S. (2020). Improvement of classroom management skills of teachers leads to creating positive classroom climate. International Journal of Educational Research Review, 5 (1), 10-25. DOI: 10.24331/ijere.646832 
Halimah, L. \& Sukmayadi, V. (2019). The role of "jigsaw" method in enhancing Indonesian prospective teachers' pedagogical knowledge and communication skill. International Journal of Instruction. 12, 289-304. https://doi.org10.29333/iiji.2019.12219a.

Hoon, T.S., Nasaruddin, N.F.B.M, Singh, P. (2017). Communication skills among different classroom management styles teachers. Asian Journal of University Education, 13(1), 6778.

Ihmeideh, F. M., Al-Omari, A. A., \& Al-Dababneh, K. A. (2010). Attitudes toward Communication Skills among Students'-Teachers' in Jordanian Public Universities. Australian Journal of Teacher Education, 35(4), 1-11. http://dx.doi.org/10.14221/ajte.2010v35n4.1.

Ihtiyaroglu, N. (2018). Analyzing the relationship between happiness, teachers' level of satisfaction with life and classroom management profiles. Universal Journal of Educational Research 6(10), 2227-2237, DOI: 10.13189/ujer.2018.061021

Juta, A. \& Wyk, C.V. (2020). Classroom management as a response to challenges in mathematics education: Experiences from a province in South Africa. African Journal of Research in Mathematics, Science and Technology Education, 24(1), 21-30, DOI: 10.1080/18117295.2020.1731646.

Kadioglu-Ates, H. \& Bulut, R. C. (2019). The relationship between communication skills and organizational cynicism levels in the secondary school teachers'. Jass Studies-The Journal of Academic Social Science Studies, 75, 81-92.

Karakaya, E.G. \& Mumin, M. (2018). Social skills, problem behaviors and classroom management in inclusive preschool settings. Journal of Education and Training Studies, 6(5), 123-134, doi:10.11114/jets.v6i5.3076

Khan, A. Khan, S., Zia-Ul-Islam, S. Khan, M. (2017). Communication skills of a teacher and its role in the development of the students' academic success. Journal of Education and Practice, $8(1), 18-21$.

Korkut-Owen, F. ve Bugay, A. (2014). Developing a communication skills scale: Validity and reliability studies. Mersin University Journal of the Faculty of Education, 10(2), 51- 64.

Korkut-Owen, F. ve Demirbas-Celik, N. (2017). Communication according to personality traits in adults. International Academic Research Congress. Turkey: Antalya. https://www.inescongress.com/

Laut, J. (1999). Classroom management: Beliefs of preservice teachers and classroom teachers concerning classroom management styles. Paper presented at the Fall Teachers Education Conference (Charleston, SC. October 1999), 1-12.

Martin, N. \& Baldwin, B. (1993). An examination of the construct validity of the inventory of classroom management style, Paper presented at the Annual Conference of the MidSouth Educational Research association, New Orleans, LA. November. Retrieved January 24, 2021, from https://files.eric.ed.gov/fulltext/ED365723.pdf

Moradi, N. (2020). The impact of classroom management on students' communication skills in English Language Classrooms. Language Testing in Focus, 2, 22-33. DOI: 10.32038/ltf.2020.02.03.

Neuman, W. L. (2013). Toplumsal Arastırma Yontemleri Nicel ve Nitel Yaklasimlar-2.[Social Research Methods Quantitative and Qualitative Approaches]. Istanbul: Yayinodasi Yayinlari.

Obiekwe, K.K \& Ogbo, R.N. (2020). Relationship between teachers' classroom management styles and pupils' discipline in public primary schools in Anambra State, Nigeria. International Journal of Scientific and Research Publications, 10 (3), 392-398. http:// dx.doi.org/10. 29322/IJSRP.10.03.2020.p9946.

Pektas, H.S. \& Saygili, G. (2010). An analysis of classroom management approaches of teachers: The case of Turkey. European Researcher, 69 (2), 372-381. 
Ozgok, D. ve Ciftci, S. (2020). The study of working together levels and communication skills of class teachers. The Journal of International Lingual Social and Educational Sciences, 6(2), 208-218. Doi: https://doi.org/10.34137/jilses.83568

Pallant, J. (2016). SPSS Survival manual: A step by step guide to data analysis using SPSS for Windows ( $\left.6^{\text {th }} \mathrm{Ed}\right)$. Open University Press

Punch, K. F. (2011). Sosyal Arastırmalara Giris. In: D. Bayrak, H., Bedir Arslan, \& Zeynep Akyuz (Eds.). Introduction to Social Research. Ankara: Siyasal Kitabevi.

Ritter, J., \& Hancock, D. (2007). Exploring the relationship between certification sources, experience levels, and classroom management orientations of classroom teachers. Teaching and Teacher Education, 23, p.1206-1216. https://doi.org/10.1016/j.tate.2006.04.013.

Sadik, F. (2016). Investigating primary school teachers' views about their classroom management behavior. Journal of Advances in Humanities and Social Sciences, 2(2): 7684.

Sezer, F., Aktan, S., Tezci, E., ve Erdener, M. A. (2017). The investigating of teachers' life styles and classroom management profiles in terms of some variables. Turkish Studies, 12 (33), 167-184. http://dx.doi.org/10.7827/TurkishStudies.12680.

Siddiq, F., Scherer, R. \& Tondeur, J. (2016). Teachers' emphasis on developing students' digital information and communication skills (TEDDICS): A new construct in 21st century education.Computers \& Education. 92-93, January-February, p.1-14. https: //doi.org /10.1016/ j. compe du.2015.10.006.

Sahin, A. (2015). Comprehending elementary school teachers' classroom management approaches. The International Journal of Progressive Education, 11, 131-139.

Talsik, E. (2015). Investigating the classroom management profiles of in-service music teachers' in Turkey. Journal of Education and Sociology. 6 (1), 554-557. https://doi.org/10.7813/jes.2015/6-1/97.

Tabachnick, B.G. ve Fidell, L.S. (2007). Using multivariate statistics (5. Baskı). Boston: Pearson Education

Toprakci, E. (2004). Sinif orgutunun yonetimi. [Classroom management]. Ankara: Utopya Yayinlari.

Toluc, G. (2020). Examining the relationships between university students' social anxiety levels and communication skills by gender. (Master Thesis). Turkish National Thesis Center (Thesis no. 642320).

Ugurlu, C.T. (2013). Communication skills of teachers and the effect of emphatic tendency behavior on levels of liking of children. Pegem Journal of Education \& Instruction, 2, 5162.

UnlU, I. (2020). An analysis of the relationship between class teachers' thinking styles and their class management styles. (Master Thesis). Turkish National Thesis Center (Thesis no. 640759).

Wolfgang, C. H., \& Glickman, C. D. (1980). Solving discipline problems: Strategies for classroom teachers. Boston: Allyn and Bacon.

Yesil, H. (2010). The relationship between candidate teachers' communication skills and their attitudes towards teaching profession. Procedia - Social and Behavioral Sciences, 9, 919922. https://doi.org/10.1016/j.sbspro.2010.12.259

Yilmaz, K. (2009). Primary school teachers' views about pupil control ideologies and classroom management styles. Cypriot Journal of Educational Sciences, 4, 157-167.

Yilmaz, K. (2011). The relationship between primary school teachers' classroom management styles and their views on democratic values. Journal of Values Education, 9(21), 147-170.

Yurtal, F. \& Yasar, M. (2018). Peer bullying in classes according to teachers' classroom management profiles. SDU International Journal of Educational Studies, 5(2), 64-75. 
Yusof, F.M. \& Halim, H. (2014). Understanding Teacher Communication Skills. Procedia - Social and Behavioral Sciences, 155, 471-476. https://doi.org/10.1016/j.sbspro.2014.10.324

\section{Biographical notes:}

Dr. Okay Demir (corresponding author) works as a teacher at the Malatya Science and Art Centre affiliated to the Turkish Ministry of National Education. His fields of study are curriculum and instruction, educational philosophy, education history and educational technologies.

Prof. Dr. Süleyman Nihat Şad is a faculty member at the curriculum and instruction department in Inonu University, Malatya, Turkey. His main research areas of interest include instructional technologies, teacher training, parental involvement, quantitative, qualitative and mixed methods research, and measurement and evaluation in education. 